\title{
QUALITY IMPROVEMENT OF PALM KERNEL CAKE AS BROILER FEED USING PRE-CLEANING SYSTEM
}

\section{ROHAYA MOHAMED HALIM ${ }^{1 *}$; RIDZUAN RAMLI'; CHE RAHMAT CHE MAT'; NU'MAN ABDUL HADI'; MOHD FIRDAUS OTHMAN ${ }^{1}$ and ASTIMAR ABD AZIZ ${ }^{1}$}

\begin{abstract}
The use of palm kernel cake (PKC) in broiler feed is limited due to high fibrous material contributed mainly by dirt and shell, exceeding 6\%. The fibrous component consists of mainly insoluble mannosebased polysaccharides which is not suitable for monogastric animals such as poultry and swine. This study highlights the development of a pre-cleaning system consisting of three-stage winnowing columns to reduce the shell content in kernel by less than $4 \%$ prior to oil extraction. In this study, the palm kernels received from 21 palm oil mills were subjected to dirt and shell content analysis. To produce palm kernel with low shell content, the pre-cleaning system was optimised. Further analysis on nutrient values was also carried out for premium grade PKC produced, also known as Purafex, from the clean kernels of low shell content $(<4 \%)$ after pre-cleaning. A feeding trial was carried out to study the effect of different Purafex inclusion in the dietary treatment on the broilers performance. Results showed that the dirt and shell contents in the kernels varied from $3.48 \%-5.18 \%$. The nutrient values and quality of Purafex conformed to that of standard specifications by Malayan Edible Oil Manufacturers' Association (MEOMA). Reduction of shell and fibre in kernel reduces the crude fibre in Purafex from $\geq 15 \%$ to $\leq 12 \%$, which is far below the fibre in commercial PKC, thus, making it digestible for monogastric animals. Better performance in terms of body weight gain (BWG) and feed intake (FI) were exhibited when 15\%-30\% Purafex were included in feeding trials compared to those of $45 \%$ inclusion.
\end{abstract}

Keywords: dry separation system, palm kernel, palm kernel cake, quality.

Received: 10 June 2020; Accepted: 30 September 2020; Published online: 14 December 2020.

\section{INTRODUCTION}

Malaysia has depended mostly on imported feed, particularly for the non-ruminant sector, such as poultry and swine, where corn and soyabean are the main imported energy and protein feeds (Zahari and Wong, 2009). High demand for imported feed will cause price fluctuation and high production cost. As a result, local resources, such as palm kernel cake $(\mathrm{PKC})$, is considered as an alternative to corn

Malaysian Palm Oil Board,

6 Persiaran Institusi, Bandar Baru Bangi,

43000 Kajang, Selangor, Malaysia.

* Corresponding author e-mail: rohaya@mpob.gov.my and soyabean for animal feed application. PKC is mechanically produced as by-product using screw press after extracting oil from the palm kernel at the kernel crushing plant. This by-product is easily available throughout the year and non-competitive as human food (Roslan et al., 2015).

Nutritionally, PKC is an ideal feed for most ruminant due to the protein and crude fibre content in the range of $15 \%-20 \%$ (Chong et al., 2008). However, the use of PKC for monogastric animals such as poultry (chickens, ducks, turkeys and geese) is limited owing to high shell and dirt content which exceeded 6\% (Rohaya et al., 2005). It also contains 15\% lignin (Cerveró et al., 2010) stemming from the shells in PKC (O'mara et al., 1999) and 
18\%-21\% fibre (Nwokolo et al., 1976; Sundu et al., 2005a; Lawal et al., 2010). The fibrous material in PKC also comprises mainly of insoluble mannosebased polysaccharides. These components are not favourable for nutrients digestibility (Saenphoom et al., 2013) particularly for monogastric animals such as broiler. This type of polysaccharide possesses anti-nutritional property which hinders full nutrients utilisation in PKC, resulting in feed conversion ratio depression and reduction in weight gains by 20\%-25\% in monogastric animals (Dusterhoft and Voragen, 1991).

The quality of PKC is highly dependent on the palm kernel quality. Palm kernel consignment comprises of high dirt and shell content in the range of 6\%-11\% (Rohaya et al., 2002). Using conventional process, the PKC generated also contains high shell $(>12 \%)$ and crude fibre $(>18 \%)$ (Rohaya et al., 2017). The use of PKC as feed meals for poultry is also limited by the presence of shell. During palm kernel processing, the shells are hardly removed from the PKC due to its various sizes, shape irregularity and similar density to that of kernel residues (Roslan et al., 2015). Inefficiency of shell and kernel separation at the mill had resulted in high dirt and shell content in palm kernel, thereby contaminating the PKC at the kernel crushing plant. Several studies have been carried out to enhance the separation of shell from kernel, to obtain PKC with low shell content. Sinurat et al. (2013) used sieving method to separate shell from PKC but it was not successful as the particle size of shell was smaller than the sieve pores which used static cling and electrostatic approach (Roslan et al., 2015) to separate shell from PKC, in order to reduce the lignin and fibre content of PKC. A study by Sanni et al. (2017) reported the use of saline bath system to replace clay-water batch system in separating the shell from palm kernel. Although the system showed a promising separation efficiency, it has some limitation, in terms of having increased quantity of palm kernel and shell mixtures.

Conventionally, separation of palm kernels and shells from cracked mixture at the mill is conducted using a combination of dry and wet separation system, namely winnowing column, hydrocyclone and clay bath (Rohaya et al., 2009). However, water-based system will contribute to the generation of waste effluent which may jeopardise the environment. Thus, the aim of this study is to highlight the development of a pre-cleaning system to maximise the removal of shell in the PKC and kernels. The pre-cleaning system works based on dry separation process, reducing shell content from palm kernels between $4 \%-6 \%$, with acceptable kernel losses. Kernel with low shell content was then used as raw material for the production of premium grade PKC, known as Purafex, of superior quality as value-added product for chicken feed application.
A feeding trial was carried out to examine the effect of different Purafex inclusion in the dietary treatment on the performance of broilers.

\section{MATERIALS AND METHOD}

\section{Materials}

The palm kernel consignments were obtained from 21 palm oil mills under Sime Darby Group. Each consignment received from those mills was used as raw materials for the pre-cleaning system developed to verify the range of dirt and shell content.

\section{Pre-cleaning System Development}

The pre-cleaning system works based on dry separation process to reduce shell content in the palm kernel consignment from $\geq 6 \%$ to $\leq 4 \%$ with acceptable kernel losses. The system consists of three units of winnowing columns with three different air velocities (24, 22 and $20 \mathrm{amp}$ ) to ensure maximum shell removal to achieve the targeted parameter. Two different shell fragments are discharged at two different outlets. Small shell fragments are drawn at Column 1, followed by big shells at Column 3. Palm kernels, whole and broken, were recovered from Column 2 and 3. Figure 1 depicts the kernels and shells recovered from Column 1,2 and 3. The kernels obtained after this pre-cleaning system (low shell content) were subsequently used as raw materials for the production of high quality kernel oil and high nutrient value PKC that is highly digestible for monogastric animals.

Each column is designed with different parameters, such as air velocity, column height, inlet and outlet level and feeding ratio to achieve the desired shell and kernel ratio separation at each outlet point. It operates using forced draught (blower concept) where its air flow velocity is adjusted via a device (damper) located at the ground of each separating column (Figure 2). This damper allows alteration of the throat diameter of the column to suit the composition of the feed mixture, thus, enhancing the separation of kernel and shell through different specific gravity of the materials.

\section{Evaluation of Pre-cleaning System Performance}

The pre-cleaning system was installed at the kernel crushing plant (Figure 3). Optimisation of the system was carried out for two months to produce palm kernels with low shell content. The amount of shells in the kernels after pre-cleaning was intensively determined to optimise the most suitable air velocity to cater for different composition of 


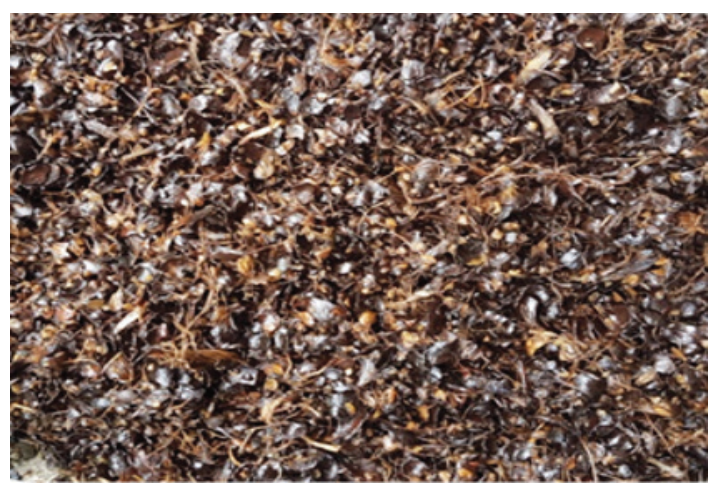

Small shell fragment and fibre (Column 1)

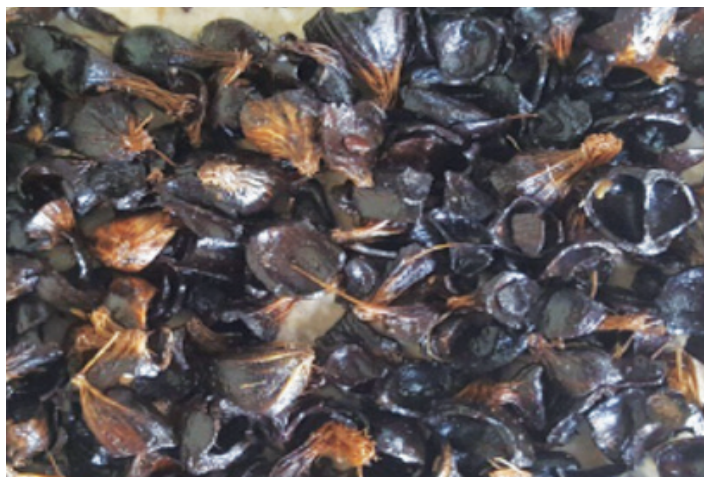

Big shell fragment (Column 3)

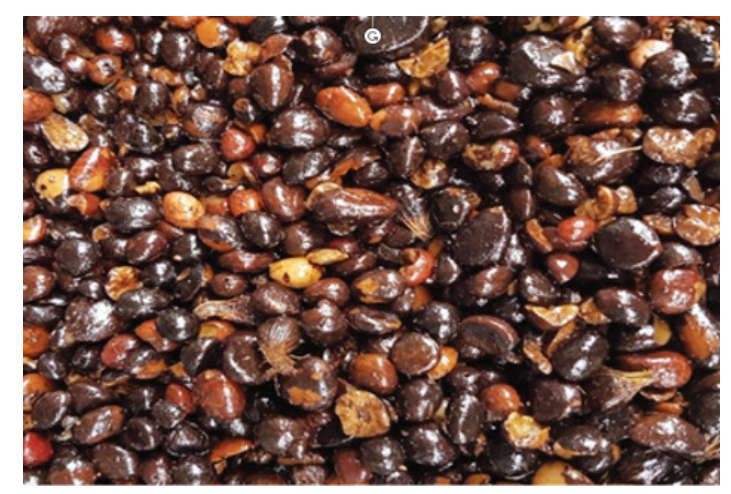

Whole kernel and big broken kernel (Column 2)

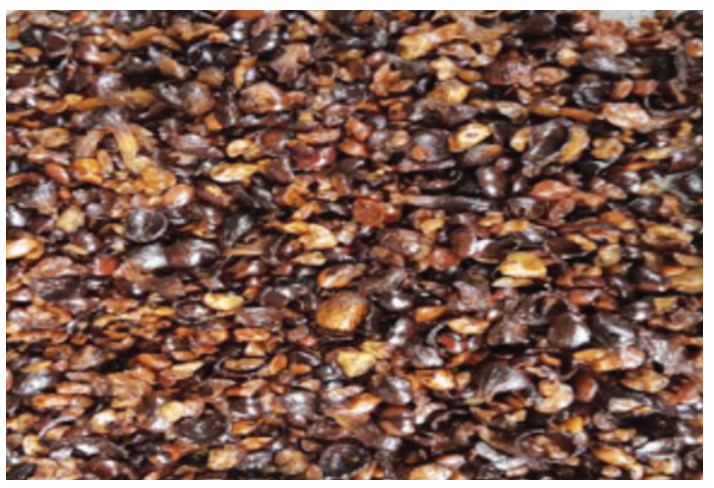

Whole kernel and small broken kernel

(Column 3)

Figure 1. Palm kernel and shell recovered from three separating columns.

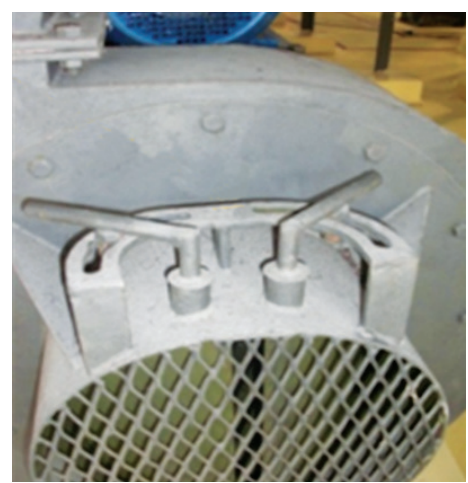

Figure 2. Adjustable damper.

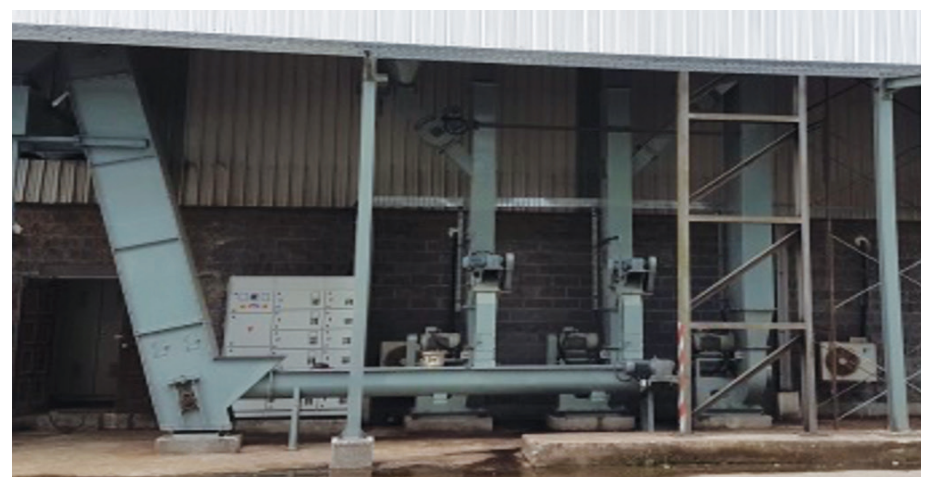

Figure 3. Pre-cleaning system installed at the kernel crushing plant. of feed materials. Performance of pre-cleaning system was evaluated based on the amount of free shells, i.e. small and big shell fragments, halfcracked and whole nuts (uncracked nuts) in kernels.

Determination of dirt and shell content in palm kernels. Approximately $1 \mathrm{~kg}$ palm kernel (PK) was taken from each consignment received from 21 palm oil mills for the study. The level of contaminants such as dirt and shell content (small and big shell fragments, half-cracked and whole nuts) prior to oil extraction process was determined following the MPOB Test Method (MPOB, 2005).
The kernel samples were sorted as whole nuts $\left(\mathrm{W}_{1}\right)$, half-cracked nuts $\left(\mathrm{W}_{2}\right)$, loose shells and debris $\left(\mathrm{W}_{3}\right)$ and stones $\left(\mathrm{W}_{4}\right)$. Prior to weighing, the whole nuts $\left(W_{1}\right)$ and half-cracked nuts $\left(W_{2}\right)$ were carefully cracked and the shells separately weighed. Total dirt and shell content was calculated in Equation (1) - (5) as follows:

$$
\begin{aligned}
& W_{1}(\%)=\frac{\text { weight of shell cracked from whole nut }}{\text { weight of PK }} \times 100 \% \\
& W_{2}(\%)=\frac{\text { weight of shell from half-cracked nut }}{\text { weight of PK }} \times 100 \%
\end{aligned}
$$


$W_{3}(\%)=\frac{\text { weight of loose shell and debris }}{\text { weight of } P K} \times 100 \%$

$W_{4}(\%)=\frac{\text { weight of stone }}{\text { weight of } P K} \times 100 \%$

Total dirt and shell content $(\%)=W_{1}+W_{2}+W_{3}+W_{4}$

\section{Production of Purafex}

Purafex, was commercially produced at the kernel crushing plant by processing clean palm kernels with low shell $(<4 \%)$ after pre-cleaning system as feeding material (Figure 4). The overall process flow for commercial production of Purafex using pre-cleaning system is illustrated in Figure 5. The nutrient values of this Purafex in terms of oil, crude protein, crude fibre, ash, moisture and shell content were further analysed. The oil content was determined according to the MPOB Test Method (2005) by extracting the Purafex samples with hexane using Soxhlet apparatus. Crude fibre was determined following the ISO6865:2000 method, while crude protein in Purafex samples was determined according to the standard methods described by ISO5983-2:2009. The shell content in Purafex samples was quantified in accordance to the MPOB Test Method (2005) as the main parameter to indicate the performance of the pre-cleaning system without contributing to high kernel losses.

\section{Feeding Trials on Broiler Growth Performance}

Birds and housing. In total, 300 of male Cobb broiler chicks (one day old) were obtained from a commercial hatchery and used in thisstudy. The birds were reared inside cages in the Climatic Controlled House $(\mathrm{CCH})$ at Energy and Protein Center, MPOB
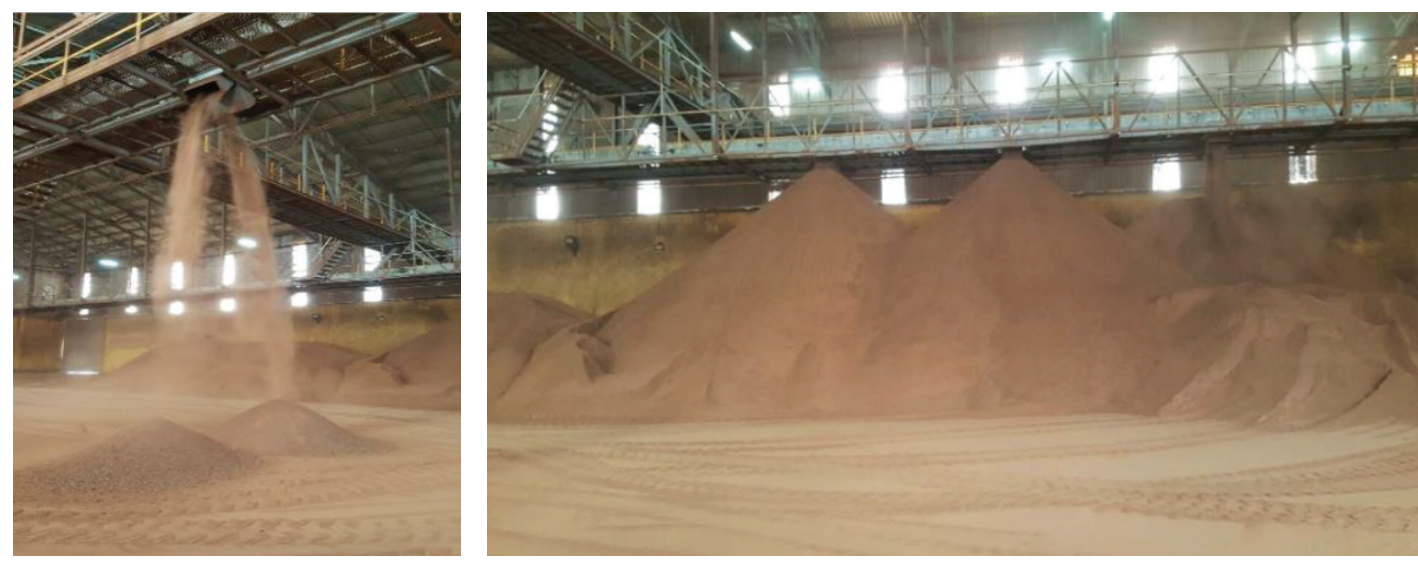

Figure 4. Commercial production of Purafex in kernel crushing plant.

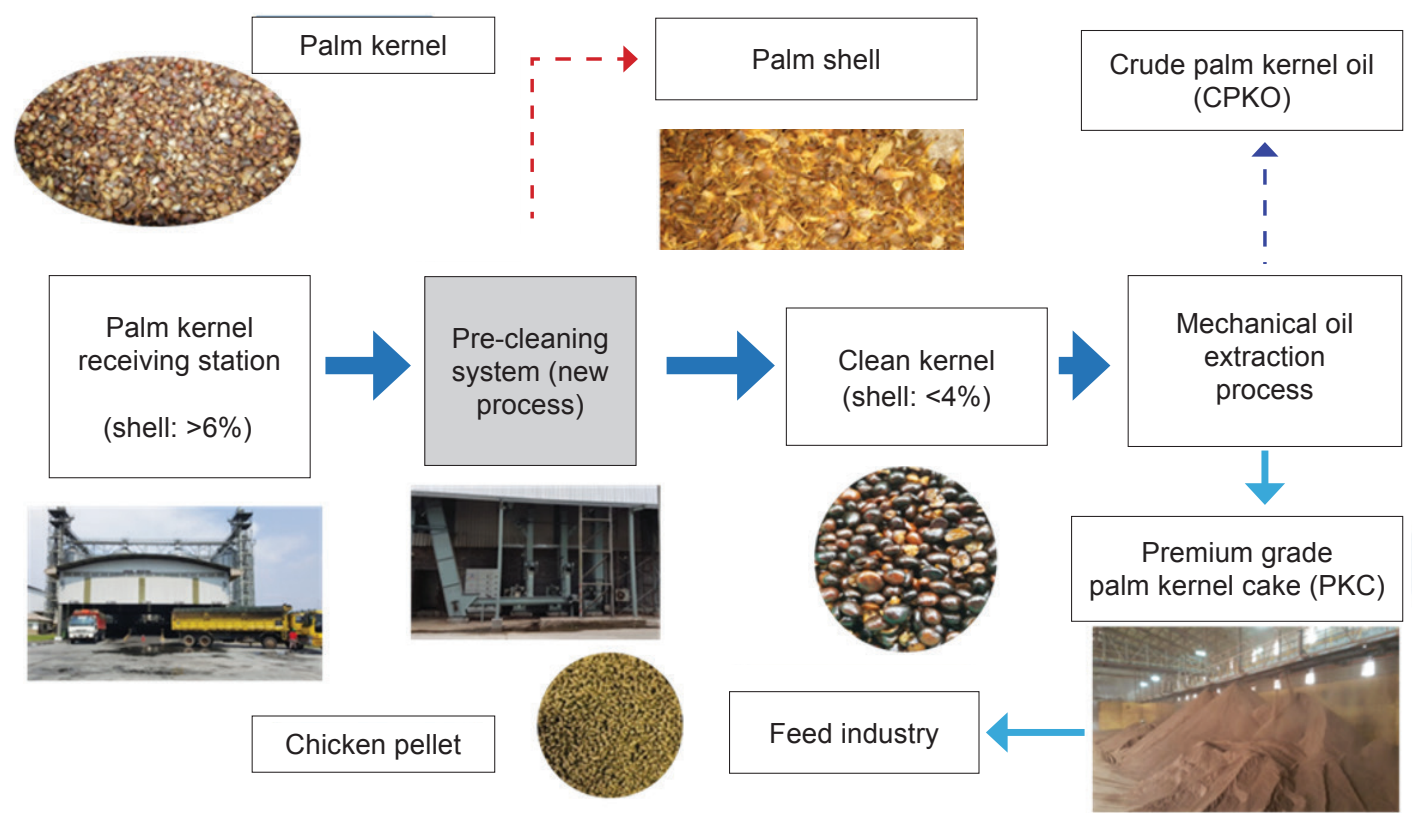

Figure 5. Process flow for commercial production of Purafex using pre-cleaning system. 
Keratong, Pahang, Malaysia. The temperature of the house was at ambient temperature and controlled through an evaporative cooling system. All birds were randomly divided into four groups; each group subjected to different Purafex inclusion in the dietary treatment, i.e. $0 \%, 15 \%, 30 \%$ and $45 \%$ (Figure 6). Each group consisted of three replications with 25 birds in each cage. Water was provided adlibitum, while light was supplied for 16:8 hr (light: dark) daily throughout the experiment. The feeding trial was conducted for 35 days.

Experimental diets. Diets were formulated according to the recommendation by Cobb 500 Management Guide (Cobb-Vantress.com, 2018). The experimental diet consisted of a corn-soyabean meal diet with four levels of Purafex, which was $0 \%$, $15 \%, 30 \%$ and $45 \%$. The formulation also consisted of palm oil, vitamins and minerals to balance the nutrient requirement for broiler growth so that it is isonitrogenous and isocaloric (Table 1).

Growth performance analysis. During the broiler experimental period, the body weight and feed intake (FI) of the broiler were recorded daily to determine the body weight gain (BWG), average daily weight gain (ADWG), FI, average daily feed intake (ADFI) and FCR for 35 days. The BWG is measured as the difference between the final and initial weight of birds at each of the weighing periods. FI is determined based on the difference between the amount of feed supplied to the birds (a)

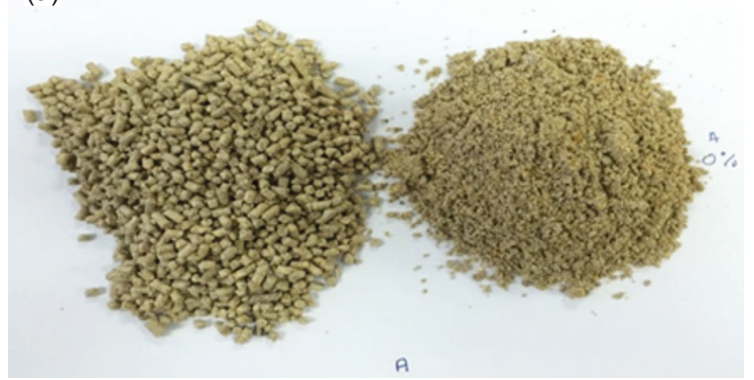

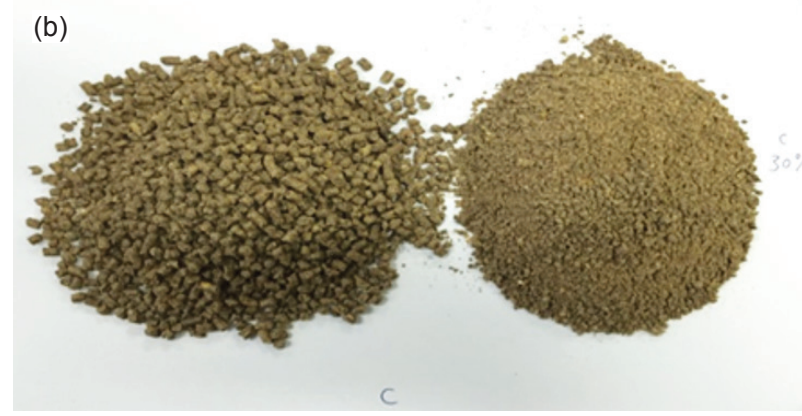

Figure 6. (a) Feed without Purafex as control, (b) feed with 30\% Purafex inclusion.

TABLE 1. INGREDIENTS AND CALCULATED ANALYSIS OF EXPERIMENTAL DIETS CONTAINING PURAFEX (palm kernel cake)

\begin{tabular}{|c|c|c|c|c|}
\hline \multirow{2}{*}{ Ingredients } & \multicolumn{4}{|c|}{ Diet $(\%)$} \\
\hline & 0 & 15 & 30 & 45 \\
\hline Purafex (palm kernel cake) & 0 & 15 & 30 & 45 \\
\hline Corn & 57 & 47 & 32.9 & 21.5 \\
\hline Soyabean meal & 24 & 21.5 & 21 & 19.5 \\
\hline Fish meal & 10 & 10.5 & 11 & 9.5 \\
\hline Rice bran & 3.6 & 3.2 & 2.8 & 2.4 \\
\hline Palm oil & 4 & 1 & 0.5 & 0 \\
\hline DiCalcium Phospate & 1.5 & 1.5 & 1.5 & 1.5 \\
\hline Vitamin premix & 0.1 & 0.1 & 0.1 & 0.1 \\
\hline Mineral & 0.1 & 0.1 & 0.1 & 0.1 \\
\hline Methionine & 0.2 & 0.2 & 0.2 & 0.2 \\
\hline Lysine & 0.1 & 0.1 & 0.1 & 0.1 \\
\hline Total & 100.6 & 100.2 & 100.2 & 99.9 \\
\hline \multicolumn{5}{|l|}{ Calculated analysis (\%) } \\
\hline Crude protein & 22 & 22 & 22 & 22 \\
\hline Fibre & 4 & 5.2 & 6.3 & 8.1 \\
\hline Fat & 3.5 & 4.5 & 6.2 & 7.3 \\
\hline Ash & 7 & 8.3 & 8.8 & 9.5 \\
\hline Metabolisable energy $\left(\mathrm{kcal} \mathrm{kg}^{-1}\right)$ & 3850 & 3850 & 3850 & 3850 \\
\hline
\end{tabular}


and the remaining of feed at the end of each feeding period.

Statistical analysis. Data were analysed using the general linear models procedure of SAS (The Statistical Analysis System). Differences among treatments were by the least significant difference at $\mathrm{P}<0.05$.

\section{RESULTS AND DISCUSSION}

\section{Dirt and Shell Content of Palm Kernels}

The crucial quality parameter for palm kernels is the shell and dirt content, which measures the impurities and foreign matters (Nordin et al., 2005). Figures $7 a$ and $7 b$ illustrate the range of dirt and shell content determined in palm kernel consignments received from 21 mills in January and February 2015. Results indicated that the dirt and shell content in the kernels varied from $3.48 \%-5.18 \%$. Most palm oil mills delivered kernels with dirt and shell content below $5.0 \%$, meeting the specification set by the Malayan Edible Oil Manufacturers' Association (MEOMA).
Quality of PKC highly depended on the quality of palm kernels as raw material. Rohaya et al. (2005) emphasised that the main contributing factor to low PKC quality is the inconsistent quality of kernels delivered to the crushing plant. The dirt and shell content was reported to be around $6 \%-11 \%$, resulting in high dirt content $(12 \%-15 \%)$ in PKC produced by the crushing plants. Shell content of more than $10 \%$ will result in low kernel oil yield, affecting the PKC feed value and accelerate the machinery wear and tear (Rohaya and Osman, 2002). Eliminating shells in kernels is unachievable due to the various sizes, irregular shapes and similar density between shells and kernels (Roslan et al., 2015). Thus, quality improvement of palm kernels is warranted.

\section{Performance of Pre-cleaning System}

Figure 8 illustrates the performance of the precleaning system from October-December 2016. It was found that by applying the correct air velocity in each column, the pre-cleaning system was capable of reducing the amount of free shell in kernel by $50 \%$. The amount of free shell in kernels before pre-cleaning varied from $2.0 \%-4.0 \%$. However, it was reduced consistently to below $3.0 \%$ after pre-cleaning.

(a)

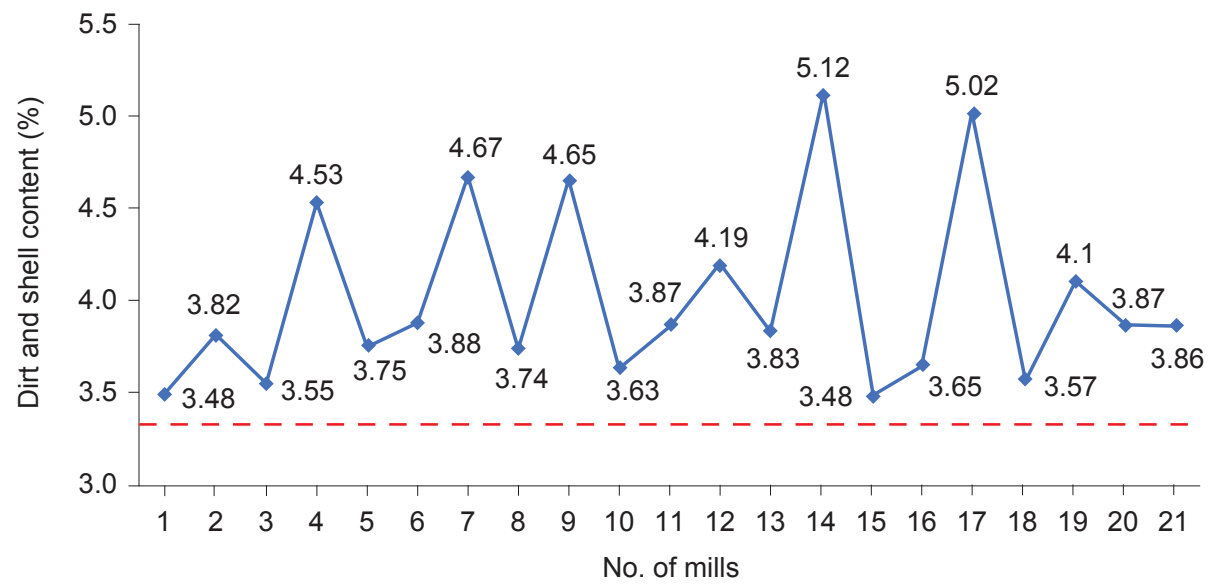

(b)

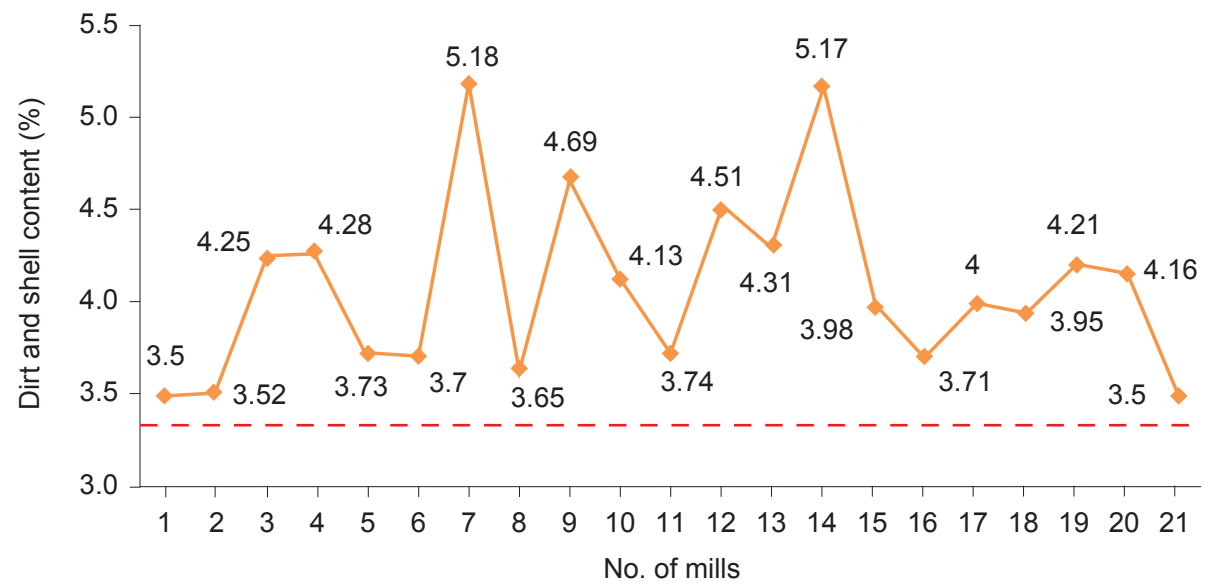

Figure 7. Dirt and shell content in palm kernel consignments for (a) January, and (b) February 2015. 


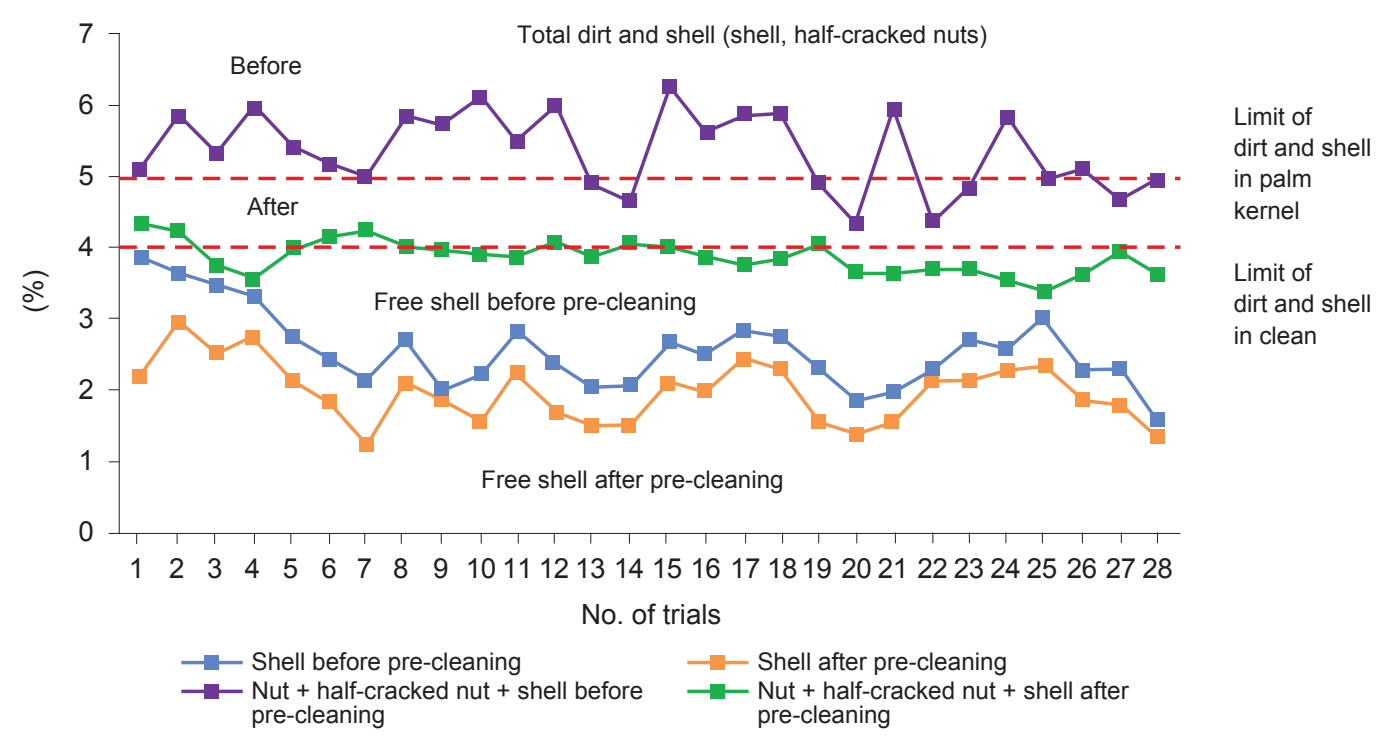

Figure 8. Performance of pre-cleaning system from October-December 2016.

The free small and big shell fragments were effectively removed by the pre-cleaning system with reasonable amount of kernel losses amounting not more than $1.6 \%$ of the sample. Kernel losses depended on the amount of small broken kernel received by the kernel crushing plant. However, the presence of high whole (uncracked) and halfcracked nuts due to inefficient cracking performance of the palm nuts at the palm oil mill, contributed to high dirt and shell content in the clean kernels. The total shell stemming from free shell, whole and halfcracked nuts fluctuated from $3.4 \%-4.4 \%$, slightly higher than the targeted performance $(<4.0 \%)$. The density of nuts is quite similar to that of kernels, where nuts tends to fall into the kernels.

The performance of the pre-cleaning system was continuously monitored for three months starting from January-March 2017. Figure 9 illustrates the separation performance of the system for free shell removal in kernels. The results indicated that the amount of free shell after pre-cleaning was maintained below the targeted limit $(<4.0 \%)$. However, the total amount of shell exceeded the limit $(>4.0 \%)$ for separation of whole and halfcracked nuts from the kernels. The air velocity applied in Column 2 and 3 was capable of removing some of the whole and half-cracked nuts present in the kernel consignments to minimise kernel losses. Based on the results, it can be concluded that the maximum limit of dirt and shell in palm kernel before pre-cleaning must not exceed $5 \%$, in order to achieve the targeted limit of $<4.0 \%$ shell in the clean kernel.

The presence of shell and half-cracked nuts together with kernels may increase the dirt and shell content in Purafex. It was observed that the amount of free shell was reduced significantly after pre-cleaning, compared to the half-cracked nuts.

\section{Proximate Values of Purafex}

The proximate values of Purafex are illustrated in Figures 10 and 11. The Purafex referred to PKC containing lower shell content $(\leq 6 \%)$ compared to the commercial PKC $(\geq 12 \%)$ and higher crude protein content $(\geq 16 \%)$ than commercial PKC $(14 \%)$. Crude protein content is directly influenced by the amount of shell; high shell content will lower the crude protein content (Rohaya and Osman, 2002). According to MEOMA trade specification for domestic contract (MEOMA, 2000), the minimum level of protein content in PKC is $14 \%$. Purafex also comprised of low crude fibre $(\leq 12 \%)$, in align with the nutrients requirement for broilers when the inclusion level of PKC is below 50\%. Reduction of shell and fibre in the kernels using pre-cleaning system also reduced the crude fibre in the PKC from $\geq 18 \%$ to $\leq 10 \%$, which was far below the fibre in the commercial PKC, thus, making it digestible for monogastric animals and ruminants.

From Figure 11, it could be seen that the oil content in Purafex fluctuated from $7.5 \%-10 \%$ depending on the efficiency of the screw press during oil extraction process. Another study by Rohaya and Osman (2002) reported that the oil content in PKC from seven conventional crushing plants ranged from $7.5 \%$ to as high as $13.2 \%$. The oil content retained in PKC is a good source of energy for feed uses (Nordin et al., 2005); however, it should be reduced to increase the kernel oil recovery as additional income to the crushing plants (Rohaya and Osman, 2002). For domestic trade, the minimum level of oil content in PKC is $8 \%$ (Nordin et al., 2005). Similar trend was also observed for moisture content of Purafex ranging from 5.8\%-8.7\%. Using conventional method, the moisture content of PKC was in the range of 
(a)

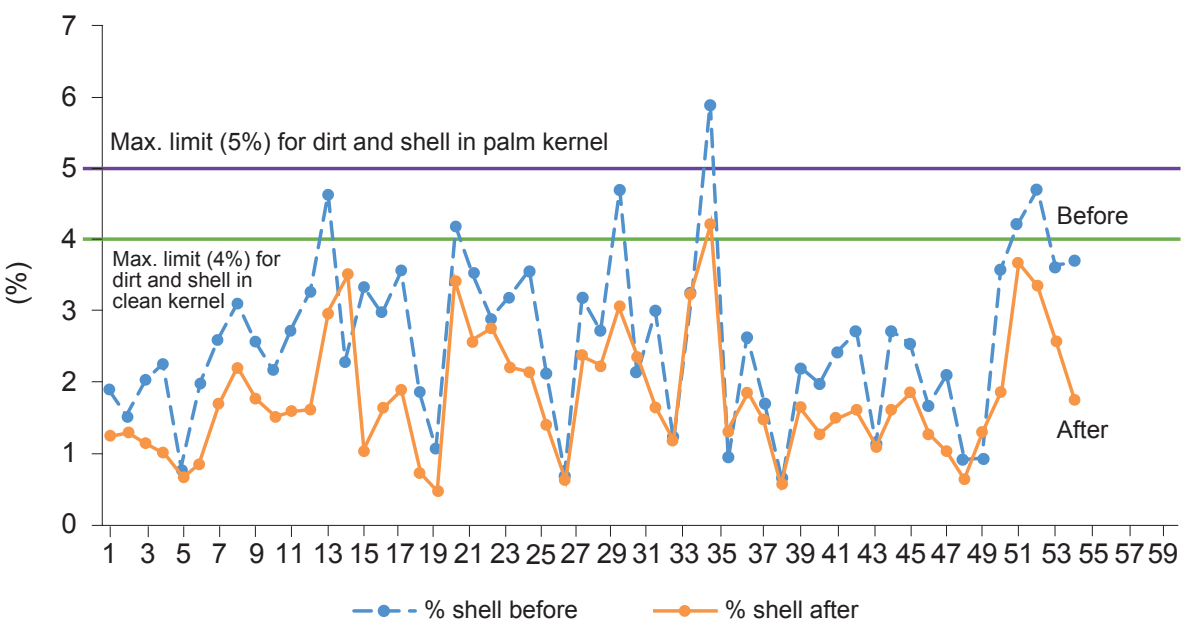

(b)

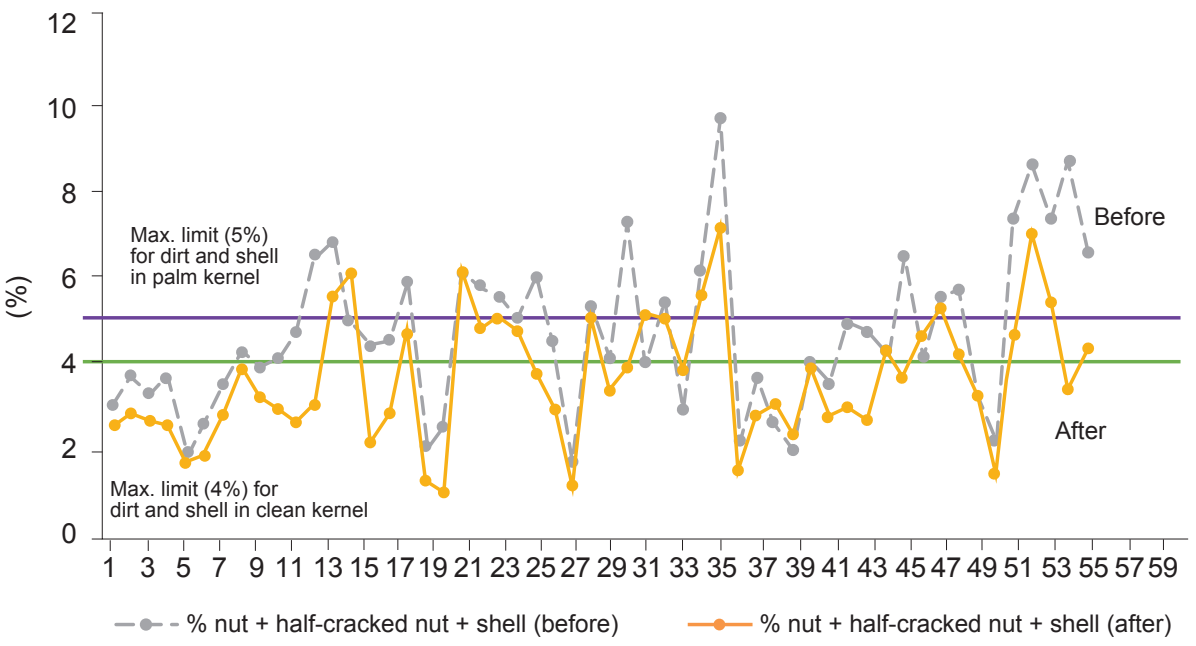

Figure 9. Removal of (a) free shell and (b) whole and half-cracked nuts by pre-cleaning system from January-March 2017.

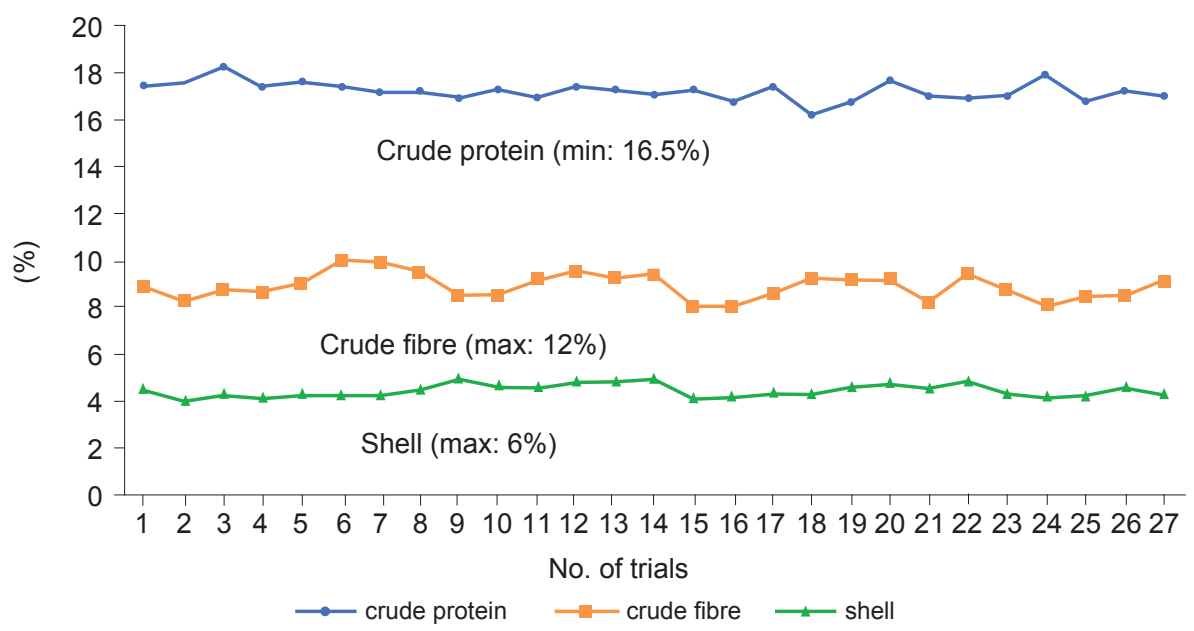

Figure 10. Crude protein, crude fibre and shell content in Purafex.

$3.3 \%-11.5 \%$ as reported by Rohaya and Osman (2002). Nordin et al. (2005) emphasised that the moisture content in PKC is influenced by moisture content in palm kernels. Hence, the moisture content of raw material must not exceed $10 \%$. The maximum levels of PKC's moisture content stipulated for domestic and export trades are $9.5 \%$ and $10 \%$ at the point of shipment, respectively (MEOMA, 2000). In addition, the ash content of Purafex was maintained below $5.0 \%$ for all trials.

The shell content in Purafex was between $4.0 \%$ $5.0 \%$, compared to $>12.0 \%$ in commercial PKC, meeting the targeted performance of below $6.0 \%$. 


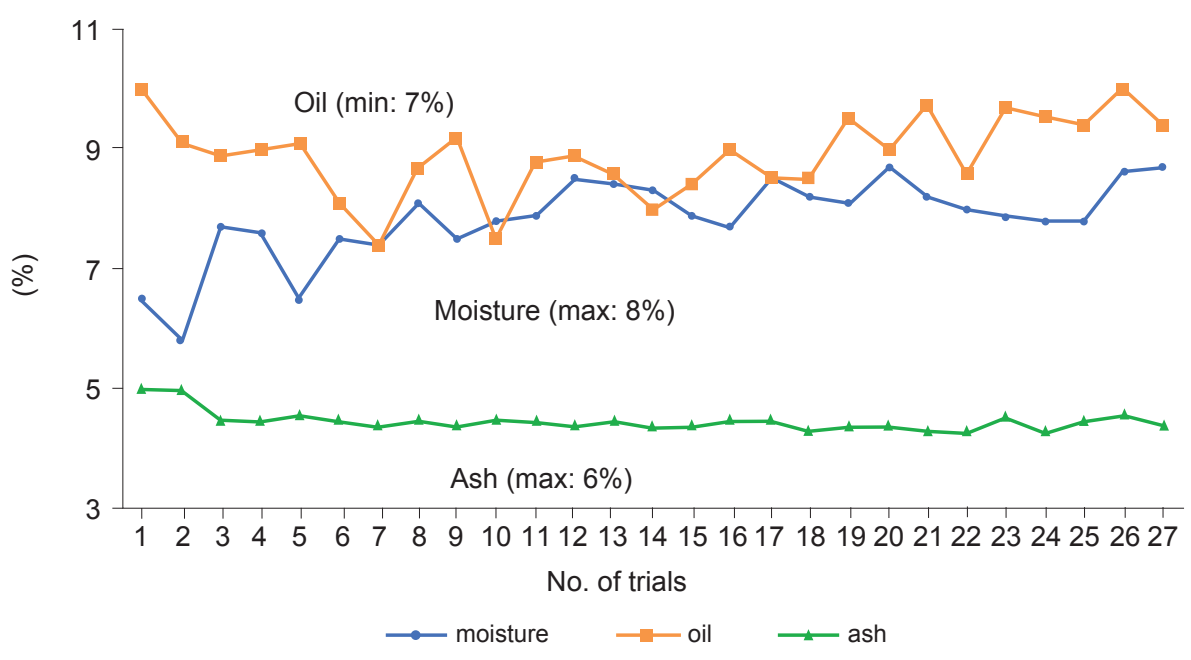

Figure 11. Moisture, oil and ash content in Purafex.

A survey conducted for seven crushing plants using conventional processing recorded the amount of shell in PKC ranging from 6.3\%-21.0\% (Rohaya and Osman, 2002). The maximum content of shell in PKC should be lower than 15\% as stipulated by MEOMA standard specification. The PKC consignment can be rejected for domestic trade if the shell content is higher than 18\% (Nordin et al., 2005). Thus, the pre-cleaning system has succeeded in reducing the shell content in Purafex, demonstrating better performance than the conventional separation system.

The crude fibre in Purafex was lower than $12 \%$, indicating better quality than commercial PKC with crude fibre more than $15 \%$. The protein content in Purafex fell within $16.0 \%-17.8 \%$, compared to $<16.0 \%$ in the commercial PKC. The comparisons of crude protein, crude fibre and shell content between Purafex and commercial PKC are shown in Figures 12a-c. Thus, the Purafex quality produced from the clean kernels with low shell content after pre-cleaning system conformed to the standard specifications by MEOMA.

\section{Effect of Broilers Chicken Fed with Purafex}

Table 2 summarises the nutritive values of the broilers fed with 15\%-45\% Purafex inclusion. The feeds were formulated through combination of energy and protein sources to provide better amino acid balance and sufficient nutrients requirement so it is isonitrogenous and isocaloric. However, the crude fibre content in diet $45 \%$ Purafex was slightly higher $(7.0 \%)$ than the required, which is less than 7\% in poultry feed (Varastegani and Dahlan, 2014). Although fibrous components in food may give negative effect on broiler growth performance (Janssen and Carré, 1985), crude fibre should be moderately incorporated in the diets which are beneficial for gizzard activity and bacterial population prevention of broilers (Montagne et al., 2003; Mateos et al., 2012). As a result, this study has limited the inclusion of Purafex up to $45 \%$ only.

As can be seen in Table 2, the crude protein had negatively correlated with the fibre content. As the inclusion level increased, the crude protein indicated a declining trend. Similarly, the oil content had also increased with the increasing Purafex inclusion. The results are in agreement with that reported by Pushpakumara et al. (2017). High shell content stemming from processing method is the prominent factor in limiting the inclusion level of PKC in broiler diets. Hence, it is crucial to improve the separation process of shell and kernels, thus, producing PKC with enhanced quality to be used as broiler feed source.

\section{Growth Performance Analyses of Starter Phase for Broilers Chicks}

Figure 13 depicts the growth performance of starter phase for the broiler chicks fed with Purafex formulated diets for 21 days. It was found that the control diet (0\% Purafex) had caused the highest body weight of broilers at $0.92 \mathrm{~kg}$, whereas diet $15 \%$ Purafex and 30\% Purafex showed no significant differences $(\mathrm{P}>0.05)$ in body weight of 0.86 and 0.85 $\mathrm{kg}$ with the control, respectively. The lowest body weight of $0.74 \mathrm{~kg}$ was obtained by diet $45 \%$ Purafex. Similar trend was observed in the BWG for diet $15 \%$ and $30 \%$ Purafex of $0.81 \mathrm{~kg}$ and $0.82 \mathrm{~kg}$, respectively, which showed no significant differences $(P>0.05)$ with the control diet, of which BWG was $0.87 \mathrm{~kg}$. This result was in line with findings by Noraini et al. (2009) and Mohd Firdaus (2014) that broiler chicks can tolerate up to $30 \%$ of PKC in the starter diet. However, broiler chicks fed with $45 \%$ Purafex (D) showed the lowest BWG of $0.7 \mathrm{~kg}$ although 
(a)

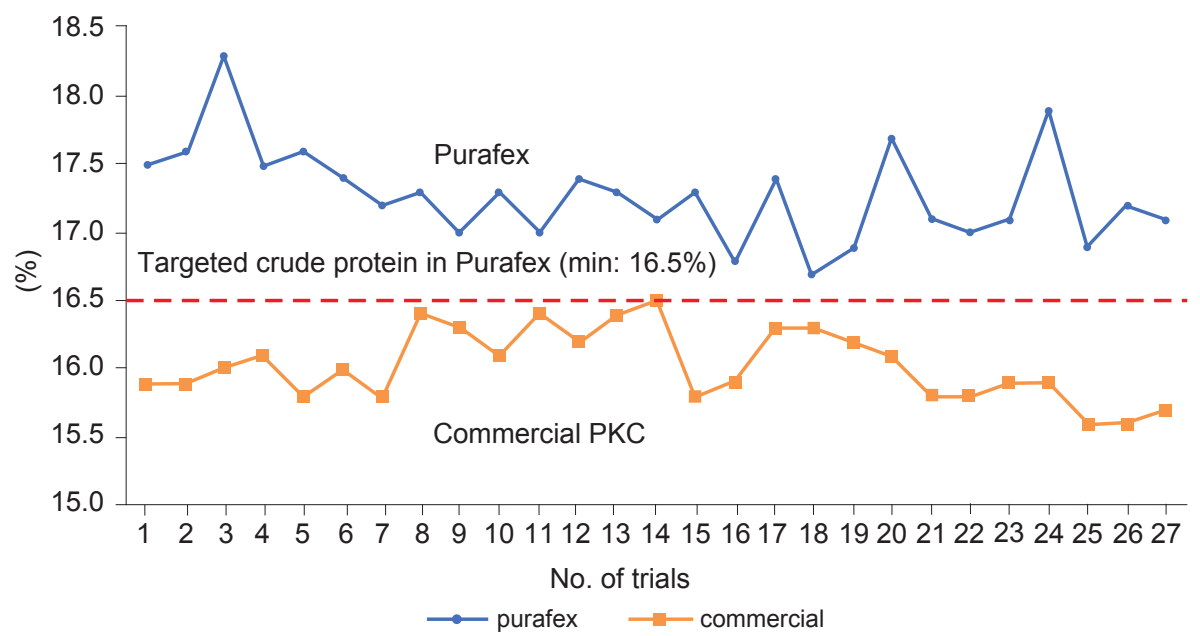

(b)

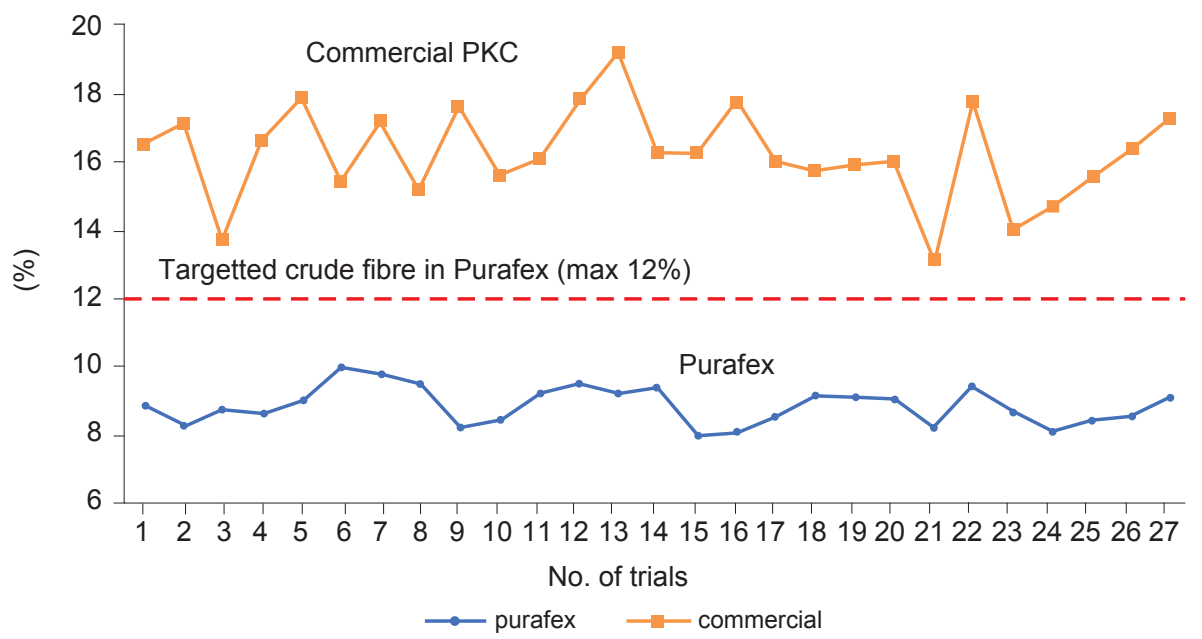

(c)

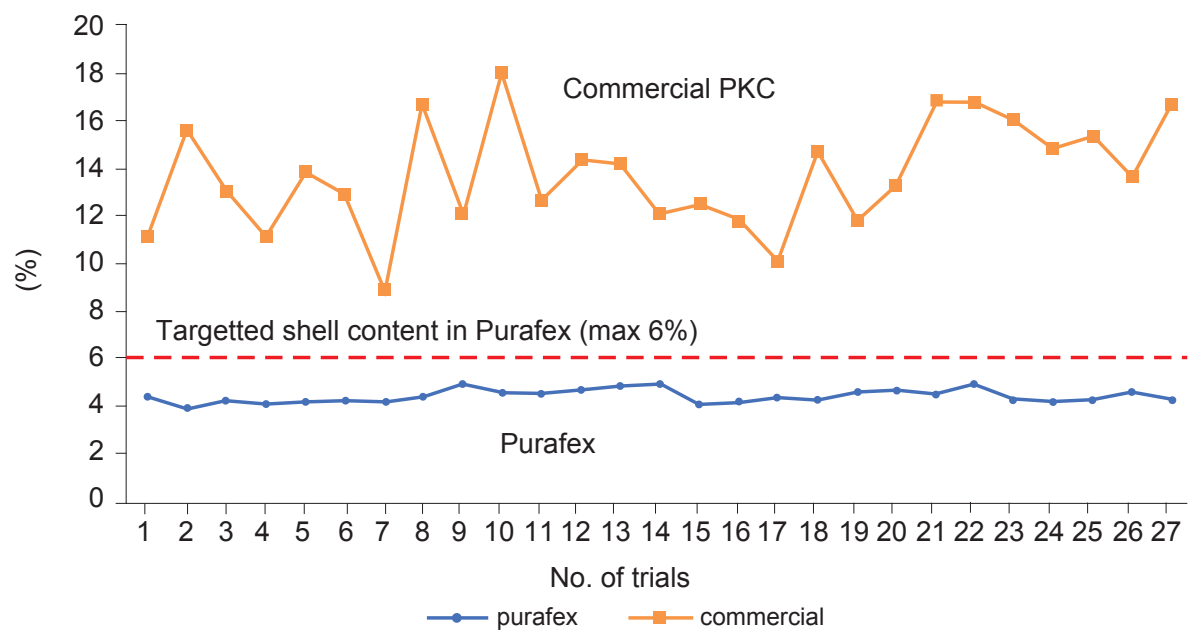

Figure 12. Comparison of (a) crude protein, (b) crude fibre, and (c) shell content in commercial palm kernel cake (PKC) against Purafex.

\section{TABLE 2. NUTRITIVE VALUE OF STARTER BROILERS FEED WITH 15\%-45\% PURAFEX INCLUSION}

\begin{tabular}{lcccc}
\hline Proximate analysis & Control & Purafex 15\% & Purafex 30\% & Purafex 45\% \\
\hline Moisture content $(\%)$ & $11.32 \pm 0.07$ & $7.83 \pm 3.47$ & $9.32 \pm 0.03$ & $8.45 \pm 0.04$ \\
Ash $(\%)$ & $8.08 \pm 0.15$ & $7.51 \pm 0.26$ & $7.95 \pm 0.50$ & $8.17 \pm 0.38$ \\
Oil content $(\%)$ & $4.17 \pm 0.03$ & $4.75 \pm 0.03$ & $5.48 \pm 0.02$ & $6.00 \pm 0.02$ \\
Crude protein (\%) & $23.08 \pm 0.26$ & $22.18 \pm 0.23$ & $21.72 \pm 0.29$ & $21.57 \pm 0.35$ \\
Fibre content (\%) & $3.70 \pm 0.30$ & $3.99 \pm 0.09$ & $5.40 \pm 0.20$ & $7.00 \pm 0.18$ \\
Gross energy $\left(\mathrm{kcal} \mathrm{kg}^{-1}\right)$ & $3908 \pm 15.40$ & $4002 \pm 5.44$ & $4064 \pm 9.86$ & $4129 \pm 7.64$ \\
\hline
\end{tabular}


(a)

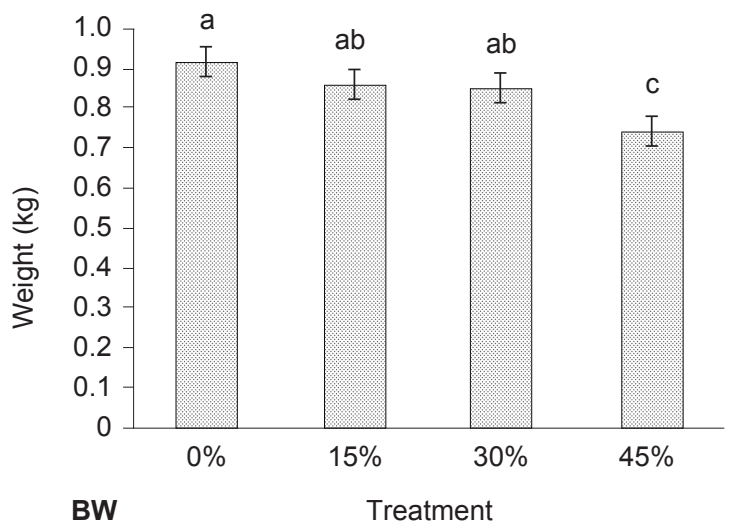

(c)

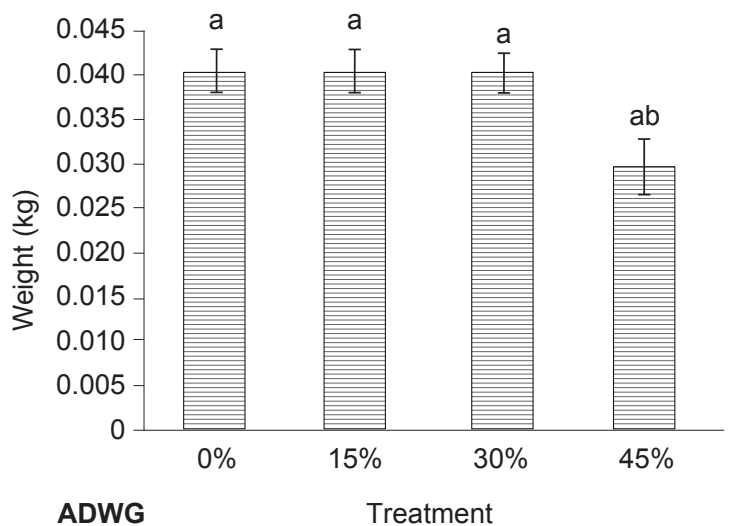

(e)

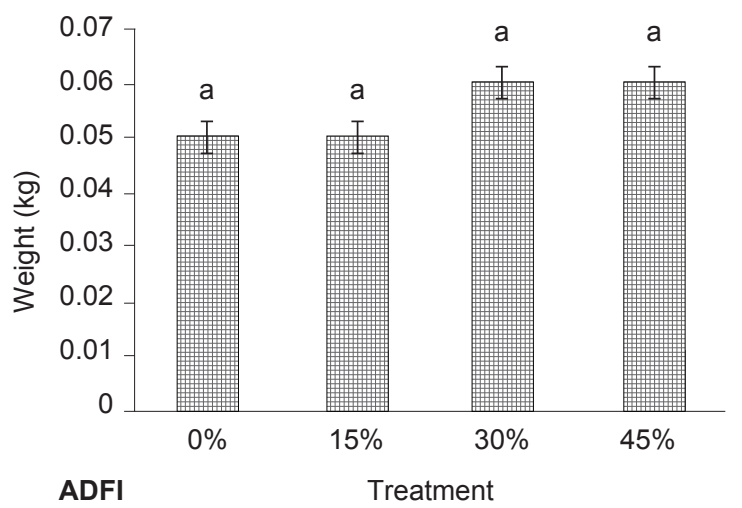

(b)

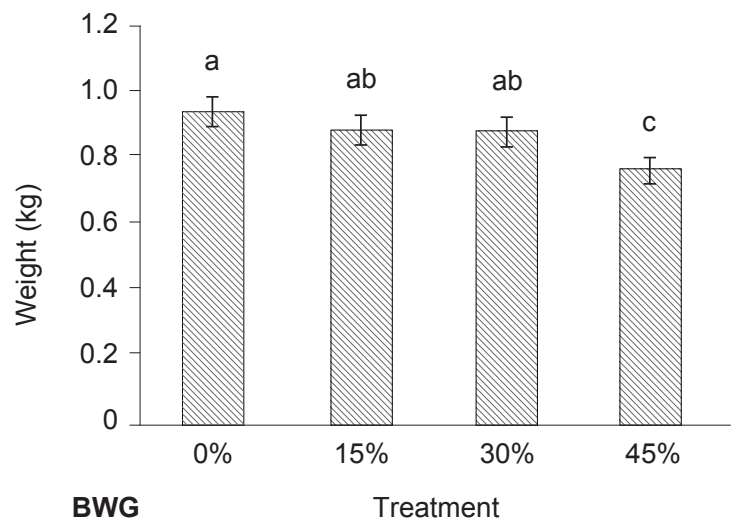

(d)
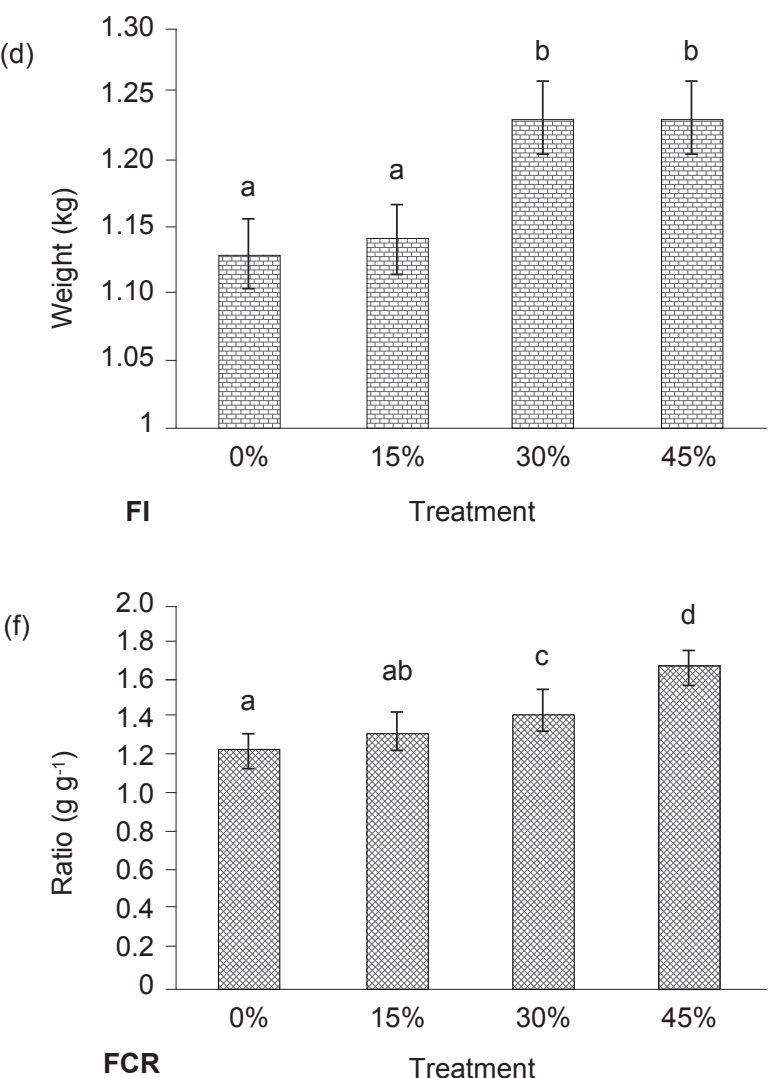

Note: ${ }^{a, b, c, d}$ Min with different superscript is significantly different $(\mathrm{P}<0.05)$.

Figure 13. Growth performance of broilers during 1-21 days age; (a) body weight (BW), (b) body weight gain (BWG), (c) average daily weight gain $(A D W G),(d)$ feed intake (FI), (e) average daily feed intake (ADFI), and ( $f)$ feed conversion ratio (FCR).

the FI was high $(1.23 \mathrm{~kg})$. This could be due to the presence of high fibre content in the formulated diet, as the increase in PKC inclusion level will reduce the palatability and availability of amino acids and energy (Onwudike, 1986). Another reason might be that the crude fibre content in diet $45 \%$ Purafex was slightly higher $(7.0 \%)$ than the required, which is less than $7 \%$ in poultry feed (Varastegani and Dahlan, 2014).

The FI of diet 30\% Purafex and 45\% Purafex shared the highest FI at $1.23 \mathrm{~kg}$ and were significantly different $(\mathrm{P}<0.05)$ from FI of control diet and diet
15\% Purafex, (1.13 and $1.14 \mathrm{~kg}$, respectively). In parallel with that, diet $30 \%$ and $45 \%$ Purafex had the highest ADFI of $0.06 \mathrm{~kg}$, while diet $0 \%$ and $15 \%$ Purafex shared the same value of $0.05 \mathrm{~kg}$ and had no significant difference $(P>0.05)$. These results indicated that broilers will consume more feed that has $30 \%$ and $45 \%$ Purafex to achieve its targeted body weight.

The FCR for control diet and diet 15\% Purafex were 1.23 and 1.33 , respectively, which did not differ significantly $(P>0.05)$, indicating the efficiency of feed towards broiler's growth which most of the 
feed were converted back to body growth of the broiler. Low FI and low FCR but high BWG proved the efficiency of the feed. In addition, diet $30 \%$ and 45\% Purafex indicated higher FCR of 1.45 and 1.66, respectively and was significantly difference with the control diet at $1.23(\mathrm{P}<0.05)$.

\section{Growth Performance of Finisher Phase for Broilers}

Figure 14 shows the growth performance of finisher phase from 22-35 days for broilers fed with $15 \%, 30 \%$ and $45 \%$ Purafex in comparison with control $(0 \%)$. The highest BWG was acquired by control diet, $0 \%(1.36 \mathrm{~kg}), 15 \%(1.37 \mathrm{~kg})$ and $30 \%$ $(1.37 \mathrm{~kg})$, and followed by diet $45 \%$ Purafex $(1.35$ $\mathrm{kg})$. However, there was no significant difference $(P>0.05)$ between the control and the experimental diets in terms of BWG. In fact, the ADWG of broilers fed with 15\% (0.097 kg) and 30\% Purafex (0.098 $\mathrm{kg}$ ) were comparable and also have no significant difference $(\mathrm{P}>0.05)$ to that of control diet $(0.097 \mathrm{~kg})$, except for diet $45 \%$ Purafex which indicated the lowest ADGW of $0.096 \mathrm{~kg}$. This study confirmed the findings reported by Ezieshi and Olumu (2004); Okuedo et al. (2005) and Bello et al. (2011), which concluded that inclusion of $45 \%$ PKC in the diet

(a)

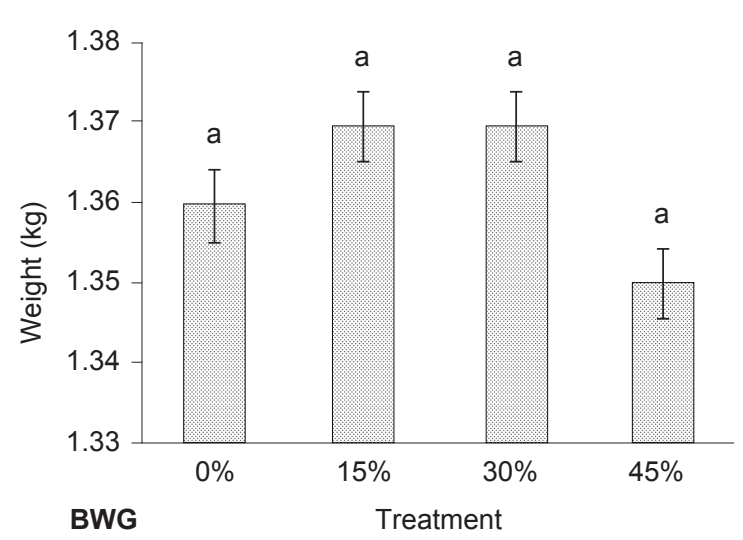

(c)

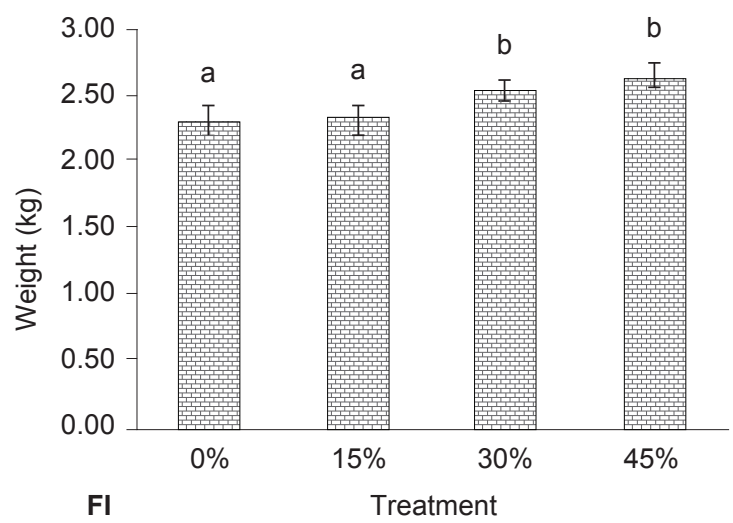

caused lower BWG and ADWG compared to that of $30 \%$ PKC. In contrast, Navidshad et al. (2016) found that even feeding 20\% low shell PKC towards broiler at finisher phase gave lower ADWG compared to diet without PKC.

The FI of the broilers has increased significantly when the level of Purafex increased from 30\%-45\%. Broilers consuming higher Purafex by $30 \%$ and $45 \%$ in their diets exhibited higher FI of $2.51 \mathrm{~kg}$ and $2.59 \mathrm{~kg}$, respectively, which were significantly different $(\mathrm{P}<0.05)$ to the control diet $(2.27 \mathrm{~kg})$ and diet 15\% Purafex $(2.3 \mathrm{~kg})$, respectively. A similar trend was indicated for ADFI, as it is in parallel with FI. The highest ADFI was consumed by diet $30 \%$ and $45 \%$ Purafex, with the values of $0.16 \mathrm{~kg}$ and $0.18 \mathrm{~kg}$, respectively, which was significantly different $(\mathrm{P}<0.05)$ with the control $(0.13 \mathrm{~kg})$ and diet $15 \%$ Purafex $(0.15 \mathrm{~kg})$. These findings showed that higher Purafex inclusion in the diets will drive the broilers to consume more feed to achieve the targeted weight. Similar finding was also reported by Sundu et al. (2005b) where the FI had increased with the increasing PKC levels in the broiler diets. Nevertheless, increasing the proportion of Purafex in the diets will increase the fibre content, which accounted for poor BWG and depression in acid (b)

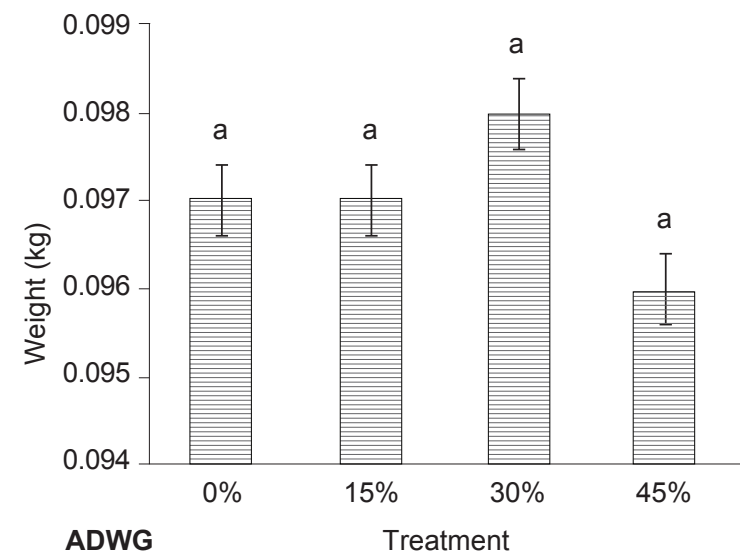

(d)

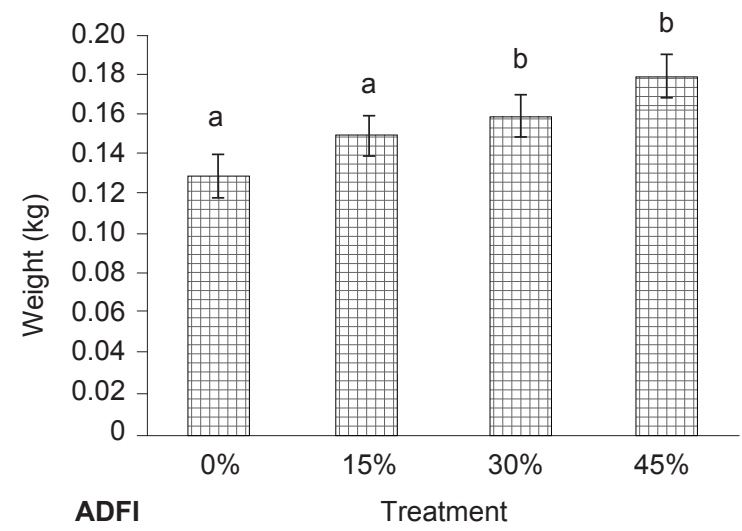

Note: ${ }^{a, b, c, d}$ Min with different superscript is significantly different $(\mathrm{P}<0.05)$.

Figure 14. Growth performance of broilers during 22-35 days age; (a) body weight gain (BWG), (b) average daily weight gain (ADWG), (c) feed intake (FI), and (d) average daily feed intake (ADFI). 
amino availability. High lignin content also results in poor digestibility in monogastric animals (Jha and Berrocoso, 2015). There was no adverse health effect on animal growth even when Purafex was given up to $45 \%$ in the diet.

\section{Growth Performance of Full Phases for Broilers}

Figure 15 depicts the growth performance of full broiler phase from Day 1 to Day 35. Results showed that all treatments reached commercial targeted minimum of $2 \mathrm{~kg}$ live final weight. Diet control (0\% Purafex) indicated the highest final body weight (FBW) was $2.27 \mathrm{~kg}$ and BWG was 2.23 $\mathrm{kg}$. However, there was no significant difference $(\mathrm{P}>0.05)$ in the FBW (2.23 and $2.22 \mathrm{~kg})$ and BWG (2.19 and $2.18 \mathrm{~kg}$ ) of broilers fed with $15 \%, 30 \%$ Purafex and the control. This finding proved the previous studies by Ezieshi and Olumu (2004), and Iyayi and Davies (2005), that broiler chicken can tolerate up to $30 \%$ in the formulation without adverse effects. The lowest FBW and BWG of 2.09 and $2.05 \mathrm{~kg}$, respectively, which were obtained by diet 45\% Purafex. According to Ezieshi and Olumu (2004), BWG of broilers fed with 45\% PKC were lower than 30\% PKC.

(a)

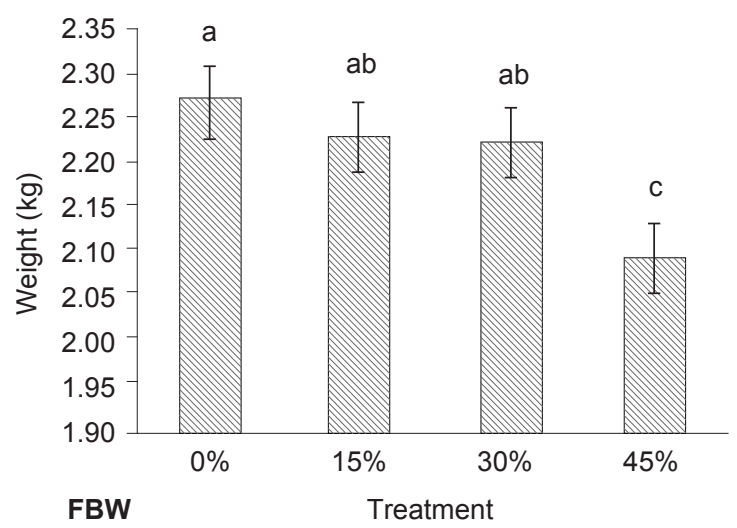

(c)

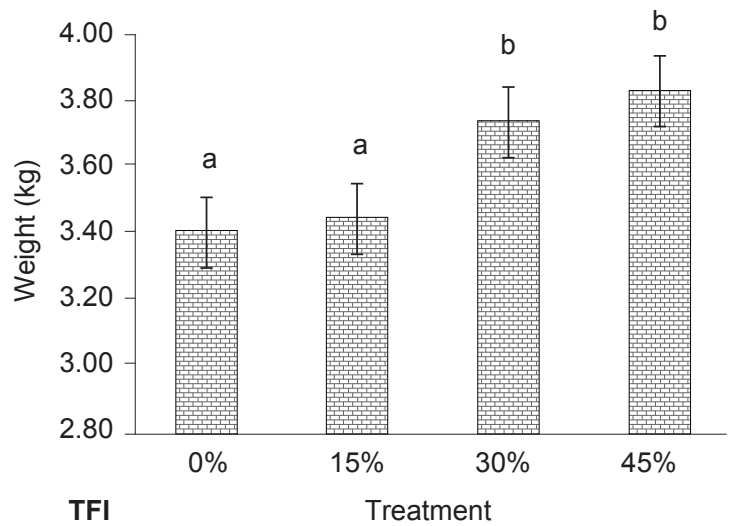

Broilers consuming high Purafex diet by $30 \%$ and $45 \%$ have recorded higher FI of 3.74 and $3.82 \mathrm{~kg}$, respectively, and was significantly different $(\mathrm{P}<0.05)$ to that of diet containing 15\% Purafex $(3.44 \mathrm{~kg})$ and control $(3.40 \mathrm{~kg})$. Feed consumed $(\mathrm{g})$ per $\mathrm{g}$ of weight gain is taken as FCR (Rasal et al., 2015). The FCR as depicted in Figure 15 had increased to 1.68 when the substitution of Purafex in the diets was more than $30 \%$ (standard set by Tegel Poultry of NZ is 1.56). The FCR of broilers without Purafex was 1.5 and substitution of $15 \%$ Purafex in broiler feed indicated an increase in FCR (1.58). Established information on optimal inclusion level of PKC in poultry diet is not available at present; however, different studies have recommended inclusion level to be in the range of 10\%-50\% depending on the types of PKC used (Fadil et al., 2014).

\section{CONCLUSION}

Palm kernels are the sole raw material for PKC production, thus the quality should be given highest priority. Since palm oil millers are unable to improve the kernel quality delivered to the crushing plant, the use of pre-cleaning system prior to oil extraction

(b)

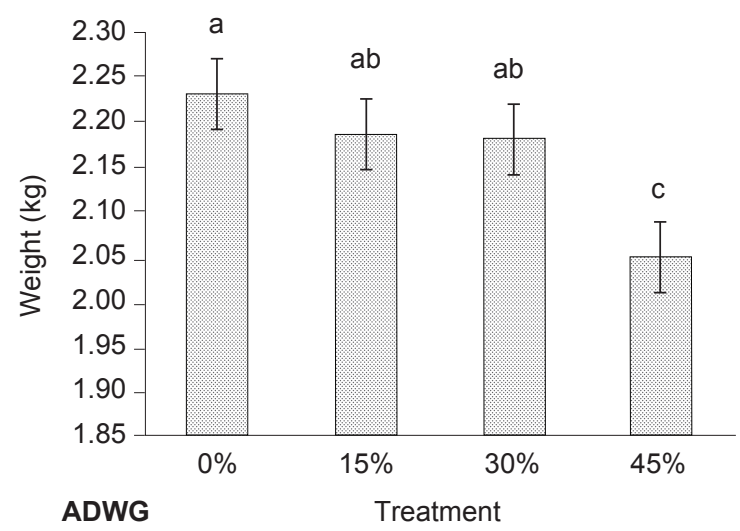

(d)

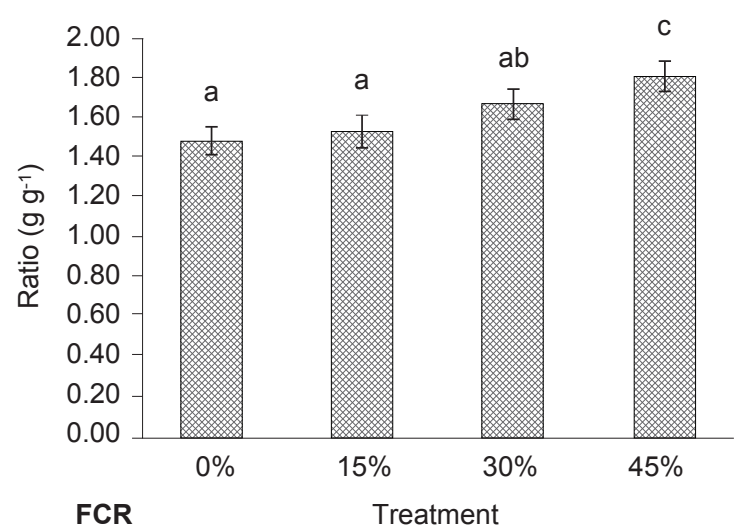

Note: ${ }^{a, b, c, d}$ Min with different superscript is significantly different $(\mathrm{P}<0.05)$.

Figure 15. Growth performance of broilers during 1-35 days; (a) final body weight (FBW), (b) body weight gain (BWG), (c) total feed intake (TFI), and (d) feed conversion ratio (FCR). 
is desirable to enhance the quality of end products. Results from the study proved that the pre-cleaning system was capable of reducing the shell content in kernels, thus, enhancing the quality of PKC (Purafex) produced. The nutrient values of Purafex surpassed those of commercial PKC, conforming to the standard specifications by MEOMA. Feeding trials on broilers showed that the inclusions of Purafex between 15\%-30\% exhibited better performance in terms of BWG and FI compared to those of $45 \%$ inclusion. However, increasing the proportion of Purafex in the dietary treatments will increase the crude fibre content, thereby alleviating the digestibility of broilers.

\section{ACKNOWLEDGEMENT}

We would like to thank the Director-General and management of MPOB for the continuous support to conduct this research.

\section{REFERENCES}

Bello, K M; Oyawoye, E O; Bogoro, S E and Dass, U D (2011). Performance of broilers fed varying levels of palm kernel cake. Int. J. Poult. Sci., 10(4): 290-294.

Cerveró, J M; Skovgaard, P A; Felby, C; Sørensen, H R and Jørgensen, H (2010). Enzymatic hydrolysis and fermentation of palm kernel press cake for production of bioethanol. Enzyme Microb. Technol., 46(3-4): 177-184.

Chong, C H; Zulkifli, I and Blair, R (2008). Effects of dietary inclusion of palm kernel cake and palm oil, and enzyme supplementation on performance of laying hens. Asian-Australas. J. Anim. Sci., 21(7): 1053-1058.

COBB (2018). Cobb 500 Broiler performance and nutrition supplement. Cobb-Vantress.com. https:/ / cobbstorage.blob.core.windows.net/guides, accessed on 4 April 2020.

Dusterhoft, E M and Voragen, A G J (1991). Non-starch polysaccharides from sunflower (Helianthus annus) and palm kernel (Elaeis guineensis) meal preparation of cell wall material and extraction of polysaccharides fractions. J. Sci. Food Agric., 55(3): 411-422.

Ezieshi, E V and Olomu, J M (2004). Comparative performance of broiler chickens fed varying levels of palm kernel cake and maize offal. Pak. J. Nutr., 3(4): 254-257.

Fadil, M; Alimon, A R; Meng, G Y; Ebrahimi, M and Farjam, A S (2014). Palm kernel cake as a potential ingredient in Muscovy ducks diet. Ital. J. Anim. Sci., 13: 112-115.

Iyayi, E A and Davies, B I (2005). Effect of enzyme supplementation of palm kernel meal and brewer's dried grain on the performance of broilers. Int. J. Poult. Sci., 4(2): 76-80.

Janssen, W M M A and Carré, B (1985). Influence of fibre on digestibility of broiler feeds. Recent Advances in Animal Nutrition (Cole, D J A and Haresign, W eds.). Butterworths, London, United Kingdom. p. 78-93.

Jha, R and Berrocoso, J D (2015). Review: Dietary fibre utilization and its effect on physiological functions and gut health of swine. Animal, 9(9): 1441-1452.

Lawal, T E; Lyayi, E A; Adeniyi, B A and Adaramoye, O A (2010). Biodegradation of palm kernel cake with multienzyme complexes from fungi and its feeding value for broilers. Int. J. Poult Sci., 9: 695-701.

Mateos, G G; Jiménez-Moreno, E; Serrano, M P and Lázaro, R P (2012). Poultry response to high levels of dietary fibre sources varying in physical and chemical characteristics. J. Appl. Poult. Res., 21(1): 156-174.

MEOMA (2000). Malayan Edible Oil Manufacturers' Association Handbook 2000 / 2001. 39 pp.

Mohd Firdaus, O (2014). Penghasilan Dedak Isirung Sawit (PKE dan PKC) Terfermentasi Melalui Sistem Fermentasi Keadaan Pepejal oleh Kulat Pencilan Tempatan Rhizopus oryzae ME01. M.Sc thesis, Universiti Kebangsaan Malaysia.

Montagne, L; Pluske, J R and Hampson, D J (2003). A review of interactions between dietary fibre and the intestinal mucosa, and their consequences on digestive health in young non-ruminant animals. Anim. Feed Sci. Technol., 108(1-4): 95-117.

MPOB (2005). MPOB Test Methods (Aini, K; Siew, W L; Tan, Y A; Nor Aini, I; Tang, T S and Nuzul, A I eds). MPOB, Bangi.

Navidshad, B; Liang, J B; Jahromi, M F; Akhlaghi, A and Abdullah, N (2016). Effects of enzymatic treatment and shell content of palm kernel expeller meal on performance, nutrient digestibility and ileal bacterial population in broiler chickens. J. Appl. Poult. Res., 25(4): 474-482.

Noraini, S; Sarah, R; Mohd Fazli, F A; Rosnizah, I and Norham, I (2009). Response of young broiler 
chickens fed increasing levels of fermented palm kernel expeller (f-PKE). Prosiding Seminar Kebangsaan Kedua Agro-Environment 2009. 24-26 March 2009. Johor Bahru, Johor.

Nordin, A B A; Venugopal, R; Amiruddin, N and Simeh, M A (2005). Palm kernel cake marketing: Constraints and prospects. Oil Palm Industry Economic J., 5: 37-46.

Nwokolo, E N; Bragg, D B and Kitts, W D (1976). The availability of amino acids from palm kernel, soybean, cottonseed and rapeseed meal for the growing chick. Poult. Sci., 55(6): 2300-2304.

Okuedo, N J; Eboh, K V; Ndidi, V I and Akanno, E C (2005). Growth rate, carcass characteristics and organoleptic quality of broilers fed graded levels of palm kernel cake. Int. J. Poult. Sci., 4(5): 330-333.

O'Mara, P P; Mulligan, F J; Cronin, E J; Rath, M and Caffrey, P J (1999). The nutritive value of palm kernel meal measured in vivo and using rumen fluid and enzymatic techniques. Livest. Prod. Sci., 60(2-3): 305316.

Onwudike, O C (1986). Palm kernel as feed a feed poultry. 2. Diets containing palm kernel meal for starter and grower pullets. Anim. Feed Sci. Tech., 16(3): 187-194.

Pushpakumara, D M S; Priyankarage, N; Nayananjalie, W A D; Ranathunge, D L and Dissanayake, D M D P (2017). Effect of inclusion of palm (Elaeis guineensis) kernel cake in broiler chicken rations. Int. J. Livest. Res., 7(2): 103-109.

Rasal, K D; Shah, T M; Vaidya, M; Jakhesara, S J and Joshi, C G (2015). Analysis of consequences of non-synonymous SNP in feed conversion ratio associated TGF- $\beta$ receptor type 3 gene in chicken. Meta Gene, 4: 107-117.

Rohaya, M H and Osman, A (2002). The quality of Malaysian palm kernel: Effect of shell content and broken kernel on the quality of final products. Paper presented at 2002 National Seminar on Palm Oil Milling, Refining Technology, Quality and Environment. 19-20 August 2002. Kota Kinabalu, Sabah.

Rohaya, M H; Osman, A and Nasrin, A B (2005). Water cooled screw press for production of feed quality palm kernel expeller (PKE) for feedstuff. MPOB Information Series No. 286.
Rohaya, M H; Nasrin, A B; Wahid, M B; Choo, Y M; Ridzuan, R; Ma, A N and Ravi, M (2009). Maximising the recovery of dry kernel and shell via a four-stage winnowing column. MPOB Information Series No. 427.

Rohaya, M H; Ridzuan, R; Che Rahmat, C M; Nu'man, A H; Nasrin, A B and Astimar, A A (2017). Highly digestible palm kernel cake (PKC) for animal feed. $М Р O B$ Information Series No. 619.

Roslan, M A H; Norhani, A and Mustafa, S (2015). Removal of shells in palm kernel cake via static cling and electrostatic separation. J. Biochem. Microbiol. Biotechnol., 3: 1-16.

Saenphoom, P; Liang, J B; Ho, Y W; Loh, T C and Rosfarizan, M (2013). Effects of enzyme treated palm kernel expeller on metabolizable energy, growth performance, villus height and digesta viscosity in broiler chickens. Asian-Australas. J. Anim. Sci., 26(4): 537-544.

Sanni, L A; Ohiare, T and Ibrahim, R O (2017). Saline bath system for separation of palm kernels from shells. J. Biochem. Microbiol. Biotechnol., 3: 1-6.

SAS (2004). SAS Institute Inc., 2002-2003 Version 9.1. Cary, NC, USA.

Sinurat, A P; Purwadaria, $\mathrm{T}$ and Pasaribu, $\mathrm{T}$ (2013). Improving nutrient values of palm kernel cake (PKC) by reducing shell contamination and enzymes supplementation. J. Ilmu Ternak dan Vet., 18(1): 34-41.

Sundu, B; Kumar, A and Dingle, J (2005a). Comparison of feeding values of palm kernel meal and copra meal for broilers. Recent Adv. Anim. Nutr. Aust. p. 15-16.

Sundu, B; Kumar, A and Dingle, J (2005b). Palm kernel meal in broilers diets, effect on chicken performance and health. World Poult. Sci. J., 62(2): 316-325.

Varastegani, A and Ismail, D (2014). Influence of dietary fibre levels on feed utilization and growth performance in poultry. J. Anim. Sci. Adv., 4(1): 422429.

Zahari, M W and Wong, H K (2009). Research and development on animal feed in Malaysia. WARTAZOA, 19(4): 172-179. 